\title{
MODELLING SUPPLEMENTATION STRATEGIES FOR BEEF STEER REARING AND FATTENING SYSTEMS IN SOUTHERN CHILE
}

\author{
Paula Toro $^{1 *}$, Adrián Catrileo², Claudio Aguilar ${ }^{1}$, and Raúl Vera ${ }^{1}$
}

\begin{abstract}
A mathematical model was developed to analyze beef production systems in Southern Chile. The study considered the identification of the main components of systems under different beef steer management strategies, using pasture with or without supplementation and back grounding cattle on pasture followed by a winter period of confined feeding with pasture silage and concentrates. Validation of model outputs using $200 \mathrm{~kg} \mathrm{LW}$ Hereford steers against real experimental data showed no significant differences $(P \geq 0.01)$ between simulated and observed final weights. In order to analyze the interaction between the stocking rate (SR) and supplementation, three SR of 2, 2.5 and 3 steers $\mathrm{ha}^{-1}$ with and without pasture silage supplementation at the rate of $5 \mathrm{~kg} \mathrm{DMd}^{-1}$ steer $^{-1}$ for the length of the entire period were simulated. Means were compared by the least significant difference (LSD, P $\leq 0.05$ ). Significant differences were found in terms of final weights, which decreased with increasing SR regardless of the supplementation level, although silage supplementation tended to reduce differences between SR. A second set of simulation runs was carried out to simulate on-farm finishing of the steers through a final phase of confined feeding based on a ration of silage and concentrates. Final weights differed between SR and systems and results showed that the optimum corresponded to 2.5 steers $\mathrm{ha}^{-1}$, since at this SR the largest income corresponded to the smallest mean cost. It is concluded that a stocking rate of 2.5 steers ha $^{-1}$ is feasible if winter supplementation is available, independently of a finishing period in feedlot.
\end{abstract}

Key words: beef cattle, supplementation, grazing systems, simulation models.

\section{INTRODUCTION}

Beef production systems in Southern Chile ( $38^{\circ} 41^{\prime} \mathrm{S}$, $72^{\circ} 25^{\prime} \mathrm{W}, 200$ m.a.s.l. and $1300 \mathrm{~mm}$ rainfall) are based on dual purpose (beef and milk) cattle. The predominant breed is Overo Colorado, crossed with Hereford and occasionally other beef breeds. Traditionally, dual purpose breeds account for nearly $80 \%$ of the total cattle population (Catrileo and Goic, 2005). According to official statistics, nearly $50 \%$ of the total dairy and beef cattle population is owned by peasant farmers (ODEPA, 2001) that run predominantly cow-calf systems with low levels of productivity and efficiency. The overall stocking density is 0.5 cattle units ha ${ }^{-1}$ devoted to livestock, on farms of less than 50 ha where the main forage resources are naturalized pastures and hay supplementation in

'Pontificia Universidad Católica de Chile, Facultad de Agronomía e Ingeniería Forestal, Av. Vicuña Mackenna 4860, Santiago, Chile. *Corresponding author (pmtoro@uc.cl).

Instituto de Investigaciones Agropecuarias, Centro Regional de Investigaciones Carillanca, Casilla 58-D, Temuco, Chile.

Received: 28 March 2008.

Accepted: 27 May 2008. winter (Catrileo and Klee, 2005). Naturalized pastures are generally old perennial ryegrass (Lolium perenne L.) white clover (Trifolium repens L.) grasslands that are degraded to various extents over time and are mixed with a variety of volunteer grasses. Pasture growth is markedly seasonal, with $60 \%$ of the total pasture yield concentrated in spring, with a small second peak in the fall.

Animal are reared, backgrounded and fattened on year-round grazed pastures. Pasture-fed finished steers can be produced if sown, well managed pastures are available, but most calves produced by small farmers are sold for backgrounding and finishing to medium and large farms that have better resources, such as sown pastures and cereal crops, and which are therefore able to finish cattle for the internal and export market. This group is the focus of the current paper.

Regardless of the situation, there is general agreement that well managed perennial ryegrass and white clover pastures are consistent with animal well being and preservation of natural resources and provide cheap feed.

Independently of size, farmers generally use rotational grazing and supplement pasture hay or silage to 
grazing animals during the low forage availability winter period. Under these conditions, conserved forages are a relatively expensive feed, and the interaction between conservation, supplementation and the on-farm stocking rate is hypothesized to have an important influence on the economic outcome of the production system.

The favourable climatic and sanitary conditions of Southern Chile, including the fact that the country is free of foot-and-mouth disease, and the relatively free access of Chile to the major beef importing countries, constitute an important incentive for the intensification of beef production. Nevertheless, weak within-country production chains and links, and the fact that most beef farms are relatively small, conspire against the expedient incorporation of new technologies and a sustained process of intensification.

The many possible combinations of variables, such as farm size, initial weight and age of animals, initial grazing date, grazing management and feed quality are associated with the economic outcome of the system. Nevertheless very few technological options have been experimentally tested, and therefore the present study used simulation to analyze the effect of changes in critical farmercontrolled system variables on the likely physical and economic performance of medium-size farms, and assess the probable impact of introducing new technological options.

The objective of the model was to evaluate the productive and economic response of the animals through different scenarios feasible to find in rearing-finishing beef systems in order to improve the income of the system.

\section{MATERIALS AND METHODS}

To develop the simulation model it was necessary to identify the main system components, subsystems and relevant variables and write the computer code, as briefly described below.

\section{Model development}

The development of the model followed the system analysis methodology advanced and used by several authors (Hoover and Perry, 1989; Aguilar et al., 2003). The model and databases were adapted to simulate performance of beef cattle grazing temperate pastures in Southern Chile. The model was programmed in Visual Basic NET (Halvorson, 2003).

The model used input and output variables (Aguilar, 1997). Input variables included: number and weight of steers; type, quantity and nutritive value of pasture and its size, quantity and nutritive value of supplement, as well as the timing of supplementation; market conditions, labor and salaries, available infrastructure and its cost. Output variables were: dry matter (DM) intake, stocking rate, final live weight (LW), LW gain; and average and marginal costs.

State variables included: digestibility of available DM; diet selection represented through a selection index, corrected for availability and digestibility; potential DM intake, crude protein (CP) and metabolizable energy (ME); $\mathrm{CP}$ and $\mathrm{ME}$ concentration of the consumed diet; energy costs of grazing and maintenance, the final energy balance that results in LW gain or loss. Daily feeding costs, including that of the pasture and eventual supplement, are computed, as well as related labor costs, financial costs due to animals, and the proportional costs due to infrastructure and taxes.

The model comprises four main modules: animals, pasture, management and market conditions. The animal component considers forage intake, nutritional requirements for maintenance, LW gain and grazing, and the energy balance that allows normal animal performance according to physiological conditions. The pasture component uses empirical growth curves determined for pastures and forages commonly used in the region. The respective module reads the average monthly potential pasture DM growth and its digestibility, and these initial values are modified according to the state of the system. The management module allows for rotational grazing, the optional use of supplements, and also represents the use of infrastructure and labor characteristic of the region. Market conditions include estimates of fixed costs like labor, infrastructure and equipment maintenance, and variable costs, such as feed and animal health.

\section{Biological components}

Animals. The endpoint of the finishing process is essentially conditioned by the animal's weight, but the age at slaughter influences meat quality and needs to be considered as well. Therefore, both variables determine the sale of the animals during simulation runs, and the user can specify age and/or minimum sale weight.

Estimation of the requirements for $\mathrm{ME}$ and $\mathrm{CP}$ were based on equations proposed by the Agricultural and Food Research Council (AFRC, 1993) and the Commonwealth Scientific and Industrial Research Organization (CSIRO, 1990). The amount of these nutrients consumed is based on the intake of forage and/or supplement, as advanced by Aguilar et al. (2003) and CSIRO (1990), whereas the interaction between forage consumption and concentrate intake was based on Aguilar (1997). Voluntary pasture intake and cattle mortality were treated as stochastic variables with user-specified mean and standard deviation. 
The model estimates daily intake of forage and supplement under grazing conditions. Initially, a potential DM intake (PDMI) is calculated reflecting the characteristics of the animal under non-limiting conditions. To this end, the model uses a reference animal weight, the current weight of the animal, and its relationship to mature weight (CSIRO, 1990). An algorithm (Aguilar et al., 2003) that computes substitution, supplementary, or additive effects between pasture and supplement intake is used to correct voluntary forage DM intake (VFDMI). The latter is further corrected by a digestibility factor (FCG) and an availability factor (FCD) as follows:

$$
\mathrm{VFDMI}=\mathrm{PDMI} \times \mathrm{FCG} \times \mathrm{FCD}
$$

where FCG is estimated based on the forage availability, and FCD is calculated from a linear equation adjusted for digestibility values between 40 and $80 \%$. The DM digestibility of diet is estimated from a selection index that corrects the average digestibility of offered forage (Aguilar et al., 2003).

Pastures. Monthly potential growth rates of the pastures, and their variation in digestibility and $\mathrm{CP}$, were used as an input to quantify the potential pasture's DM and nutrient availability. Forage digestibility was corrected for selective grazing, which in turn depended upon forage availability and stocking rate, as discussed by Aguilar et al. (2006). For finishing the animals, the silage requirement was simulated in the model assuming ad libitum intake and typical nutritive values observed at the farm level.

\section{Economic analyses}

Quantification of the economic performance of alternative systems is essential for comparing production alternatives. The simulation model therefore considers fixed and variable costs of production. Fixed costs include labor, infrastructure and machinery maintenance, and general administrative costs. Variable costs are those related to feeding and animal health. The opportunity cost of land was considered as a third component, quantified as the cost of producing forage, and that of animals. Thus, the user has access to two economic analyses, a total and an operational cost, depending upon the inclusion of opportunity costs or not.

\section{Statistical analysis}

Initial and final conditions for the experimental and simulated results were compared and the final weights were compared to validate the model using a $\mathrm{z}$ test, assuming homogeneity of variances and with a sample size of 40 animals.
In order to analyze the interaction of the stocking rate and supplementation, three stocking rates were simulated with and without grass silage supplementation at the same rate. Each scenario was replicated 20 times. Means of the output variables were compared by the least significant difference (LSD, $\mathrm{P} \leq 0.05)$.

\section{RESULTS AND DISCUSSION}

\section{Model verification}

Adequately documented experimental results useful for a thorough validation of model outputs are very scarce. Rojas and Romero (1994) carried out a grazing experiment replicated in each of five consecutive years, in the Central Valley of La Araucanía Region, Chile, using 7-8 mo of age, $200 \mathrm{~kg} \mathrm{LW}$, weaned Hereford steers introduced to the experimental pastures on April of each year and fattened until December, using an intensive system of rotational grazing. Simulation runs were carried out for a similar length of time as the experiment, and with the same amount of silage supplementation. No significant differences $(\mathrm{P} \geq$ 0.01 ) were found between simulated and observed final weights. Similarly, there were no significant differences $(\mathrm{P} \geq 0.05)$ in the amount of silage produced in each of the 5 years (Table 1$)$.

\section{Experimentation}

To study changes in economic and physical performance of the system in response to management practices, a number of scenarios, including changes in the stocking rate, levels of supplementation during the winter period, and a final fattening period in feedlot, were simulated for a 300 ha farm of the region.

\section{Stocking rate and supplementation}

The simulated system assumes that $240 \mathrm{~kg}$ Overo Colorado x Hereford calves are bought in April and are sold at $2 \mathrm{yr}$ of age or when they attain $450 \mathrm{~kg} \mathrm{LW}$, whichever occurs first. Animals grazed during the fall and winter period, from May to September, supplemented with pasture silage. The purchase price was $\$ 610 \mathrm{~kg}^{-1}$ (1 $\mathrm{US} \$=\$ 540$ ), and the sale price is $\$ 580 \mathrm{~kg}^{-1}$ (Tattersall, 2006). Three stocking rates, $2,2.5$ and 3 head ha ${ }^{-1}$, were simulated with and without grass silage supplementation at the rate of $5 \mathrm{~kg} \mathrm{DM} \mathrm{d}^{-1}$ head $^{-1}$.

Each scenario was replicated 20 times. The output variables of interest included final weight and age of steers, mean total and operational cost per $\mathrm{kg}$ LW, the financial income and the operational income of the farm. Means were compared by the least significant difference (LSD, $\mathrm{P} \leq$ 0.05) (Table 2). In all cases, simulation runs were terminated upon reaching the maximum stipulated 
Table 1. Input-output data and observed and simulated output data for five consecutive years of fattening on pasture, pasture silage conservation and supplementation. Input data and initial conditions are as reported by Rojas and Romero (1994). Simulated results are means of 20 replicates \pm SD.

\begin{tabular}{lccrrr}
\hline Variables & Year 1 & Year 2 & Year 3 & Year 4 & Year 5 \\
\hline Stocking rate, steers ha ${ }^{-1}$ & 2.5 & 3.0 & 3.5 & 4.0 & 5.0 \\
Area conserved, \% & 26.2 & 14.1 & 12.0 & 3.9 & 0 \\
Initial date (day/month) & $09 / 04$ & $15 / 04$ & $14 / 04$ & $05 / 04$ & $05 / 04$ \\
Ending date (day/month) & $10 / 12$ & $14 / 01$ & $05 / 01$ & $23 / 12$ & $18 / 01$ \\
Grazing period, days & 255 & 274 & 266 & 270 & 288 \\
Days of supplementation & - & - & 31 & 75 & 92 \\
Initial live weight, kg steer ${ }^{-1}$ & 194 & 210 & 205 & 206 & 189 \\
\hline & \multicolumn{7}{c}{ Observed } & 388 & 390 & 386 & 342 \\
Final live weight, kg steer ${ }^{-1}$ & 378 & 4668 & 4397 & 1333 & - \\
Pasture conserved DM, kg & 8160 & Simulated & & & \\
Final live weight, kg steer ${ }^{-1}$ & $374.3 \pm 8.91$ & $390.8 \pm 7.34$ & $390.6 \pm 5.51$ & $387.4 \pm 5.93$ & $341.4 \pm 9.75$ \\
Pasture conserved DM, kg & $8463 \pm 943$ & $4790 \pm 625$ & $4392 \pm 998$ & $1351 \pm 52$ & - \\
\hline
\end{tabular}

DM: dry matter.

Table 2. Simulated final live weights and financial performance in response to changes in stocking rate and pasture silage supplementation.

\begin{tabular}{|c|c|c|c|c|c|c|c|}
\hline $\begin{array}{l}\text { Stocking rate } \\
\left(\text { steers ha }^{-1}\right)\end{array}$ & $\begin{array}{c}\text { Suplemen- } \\
\text { tation } \\
\text { (yes/no) }\end{array}$ & $\begin{array}{c}\text { Final weight } \\
\text { (kg) }\end{array}$ & $\begin{array}{l}\text { Mean total } \\
\text { cost }\end{array}$ & $\begin{array}{c}\text { Mean } \\
\text { operational } \\
\text { cost }\end{array}$ & $\begin{array}{l}\text { Total } \\
\text { income }\end{array}$ & $\begin{array}{c}\text { Operational } \\
\text { income }\end{array}$ & Sales \\
\hline \multirow{3}{*}{2.0} & & $\mathrm{~kg}$ & $-\$ \mathrm{Ch}$ & $\mathrm{kg}^{-1}$ & $\longrightarrow$ millio & $\mathrm{n} \$ \mathrm{Ch}$ & $000^{\prime} \mathrm{kg}$ \\
\hline & No & $450.3 \pm 6.6 c$ & $473.6 \pm 5.5 \mathrm{a}$ & $386.2 \pm 5.5 \mathrm{a}$ & $23.3 \pm 1.8 \mathrm{c}$ & $46.7 \pm 2.1 b c$ & $270.1 \pm 3.9 \mathrm{a}$ \\
\hline & Yes & $495.6 \pm 3.6 f$ & $469.9 \pm 3.0 \mathrm{a}$ & $397.2 \pm 2.9 b$ & $26.7 \pm 1.1 \mathrm{~d}$ & $48.4 \pm 1.2 \mathrm{c}$ & $297.3 \pm 2.2 \mathrm{c}$ \\
\hline \multirow[t]{2}{*}{2.5} & No & $418.3 \pm 4.2 b$ & $501.3 \pm 4.5 \mathrm{c}$ & $414.3 \pm 4.3 \mathrm{c}$ & $18.4 \pm 2.5 b$ & $45.7 \pm 1.8 b$ & $313.7 \pm 3.2 \mathrm{~d}$ \\
\hline & Yes & $493.5 \pm 3.6 \mathrm{e}$ & $470.6 \pm 2.7 \mathrm{a}$ & $397.6 \pm 3.1 \mathrm{~b}$ & $33.1 \pm 1.2 \mathrm{e}$ & $60.1 \pm 1.6 \mathrm{~d}$ & $370.1 \pm 2.8 \mathrm{e}$ \\
\hline \multirow[t]{2}{*}{3.0} & No & $307.7 \pm 13.2 \mathrm{a}$ & $653.2 \pm 25.1 d$ & $562.7 \pm 23.7 \mathrm{~d}$ & $-25.5 \pm 5.9 \mathrm{a}$ & $-0.5 \pm 6.6 \mathrm{a}$ & $276.9 \pm 11.8 b$ \\
\hline & Yes & $466.9 \pm 7 d$ & $492.6 \pm 6.7 b$ & $419.6 \pm 6.4 c$ & $28.7 \pm 3.2 \mathrm{~d}$ & $59.0 \pm 3.5 \mathrm{~d}$ & $420.2 \pm 6.3 f$ \\
\hline
\end{tabular}

Vertical means with different letter differ significantly $(\mathrm{P} \leq 0.01)$.

age of sale of $301 \mathrm{~d}$. On the other hand, significant differences were found in terms of final weights, which decreased with increasing stocking rate regardless of supplementation level, although silage supplementation tended to reduce differences between stocking rates. All associated costs increased with increasing stocking rates due to falling final weights (Figure 1). These results are in accordance with what was reported by Rojas et al. (2004), who used similar stocking rates at 2.5 steers $\mathrm{ha}^{-1}$, but in the experiment LW gain per hectare was higher, probably due to the use of a higher amount of supplement.
Unsupplemented LW production per hectare increased initially but then fell at the highest stocking rate due to limited forage availability. When silage was provided, production per hectare increased (Table 3) although at a decreasing rate at the highest stocking rate, again due to low forage availability during the non-supplemental period.

Total and operational income initially increased with stocking rate in all simulated systems, after which the diminishing daily weight gains did not compensate for the increase in the number of animals (Table 2). 


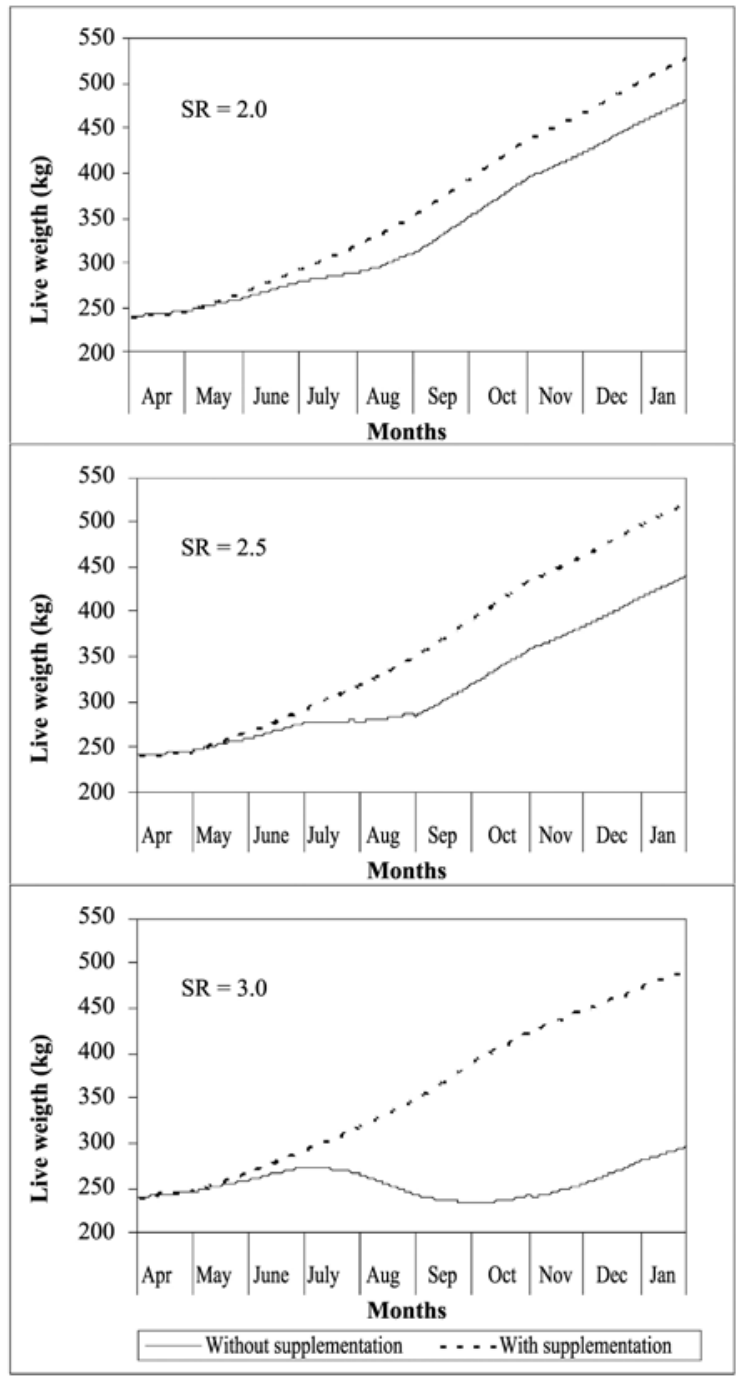

Figure 1. Simulated effects of three stocking rates (SR, steers $\mathrm{ha}^{-1}$ ) and supplementation on the evolution of the live weight of grazing steers.

Table 3. Simulated weight gain per hectare at different stocking rates, with/without pasture silage supplementation.

\begin{tabular}{cccc}
\hline Stocking rate & \multicolumn{2}{c}{ Not supplemented } & Supplemented \\
\hline steers ha ${ }^{-1}$ & & $\mathrm{~kg} \mathrm{ha}^{-1}$ & \\
\cline { 2 - 2 } 2.0 & 540 & & 631 \\
2.5 & 596 & 784 \\
3.0 & 383 & 861 \\
\hline
\end{tabular}

As expected, the inflexion point is reached first in the unsupplemented treatments, whereas supplementation partially compensated for the increased stocking rates.

\section{Stocking rate, supplementation and feedlot finishing}

A second set of simulation runs was carried out to simulate on-farm steer finishing through a final phase of confined feeding. This last phase lasted $80 \mathrm{~d}$, and was based on a ration of silage and concentrates containing 2.3 Mcal EM kg ${ }^{-1}$ DM, $14 \%$ CP and a cost of $\$ 50 \mathrm{~kg}^{-1} \mathrm{DM}$ with the objective of achieving a final weight of 480 to $540 \mathrm{~kg}$ at an age about 20 months. The remaining conditions were as described before.

Age at sale was the factor determining the length of the simulated period, which in all cases lasted $380 \mathrm{~d}$. As shown in Table 4, final weights differed between stocking rates and systems, but the differences are smaller than those reported in Table 1, due to compensatory gains realized during the feedlot period.

The calculated mean costs and total income (Table 4) show that the optimum is 2.5 steers $\mathrm{ha}^{-1}$, since this stocking rate provides the highest income at the lowest mean cost. Comparison to the previous set of simulations shows that at stocking rates of 2 and 2.5 steers ha $^{-1}$, the financial income of unsupplemented systems increases by 17 and $22 \%$, respectively, whereas supplementation allows increases of 22 and 44\%, respectively.

\section{CONCLUSIONS}

The use of silage supplementation presented a positive economic and productive effect on the final live weight of the animals, regardless of the stocking rate.

Increasing the stocking rate up to 2.5 steers ha $^{-1}$ is feasible if winter supplementation is available, independently of a finishing period in the feedlot.

Although it is feasible to increase the stocking rate up to 3 steers ha-1 with the highest live weight gain per hectare $(861 \mathrm{~kg})$, the weight of the animals individually will be lower because of a low availability of pasture, irrespective of the amount of supplementation.

\section{ACKNOWLEDGEMENTS}

This research was funded by FONDECYT Grant 1050740 . 
Table 4. Mean and standard deviation for indices of physical and economic performance of the system as a function of stocking rate and supplementation.

\begin{tabular}{|c|c|c|c|c|c|c|c|}
\hline Stocking rate & $\begin{array}{l}\text { Suplemen- } \\
\text { tation }\end{array}$ & $\begin{array}{c}\text { Final } \\
\text { weight }\end{array}$ & $\begin{array}{l}\text { Total mean } \\
\text { cost per kg } \\
\text { live weight }\end{array}$ & $\begin{array}{l}\text { Operational } \\
\text { mean cost per } \\
\text { kg live weight }\end{array}$ & $\begin{array}{c}\text { Total } \\
\text { income }\end{array}$ & $\begin{array}{l}\text { Operational } \\
\text { income }\end{array}$ & $\begin{array}{c}\text { Live } \\
\text { weight } \\
\text { sales }\end{array}$ \\
\hline Steers ha ${ }^{-1}$ & yes/no & kg steer ${ }^{-1}$ & $-\$$ & $\longrightarrow$ & $\longrightarrow$ millic & $\mathrm{n} \$ \mathrm{Ch}$ & $000^{\prime} \mathrm{kg}$ \\
\hline \multirow{2}{*}{2.0} & no & $496.7 \pm 6.6 b$ & $521.5 \pm 3.4 \mathrm{~b}$ & $433.5 \pm 5.8 \mathrm{a}$ & $29.1 \pm 2.0 \mathrm{~b}$ & $55.3 \pm 2.5 \mathrm{a}$ & $298.0 \pm 4.0 \mathrm{a}$ \\
\hline & yes & $540.4 \pm 3.9 \mathrm{e}$ & $517.8 \pm 2.7 \mathrm{a}$ & $440.7 \pm 3.2 b$ & $32.8 \pm 1.1 \mathrm{c}$ & $57.8 \pm 1.5 b$ & $324.2 \pm 2.4 b$ \\
\hline \multirow[t]{2}{*}{2.5} & no & $468.8 \pm 5.4 \mathrm{a}$ & $543.2 \pm 5.0 \mathrm{c}$ & $457.4 \pm 5.2 \mathrm{~d}$ & $26.6 \pm 2.1 \mathrm{a}$ & $56.8 \pm 2.4 b$ & $351.6 \pm 4.0 \mathrm{c}$ \\
\hline & yes & $533.4 \pm 4.5 \mathrm{~d}$ & $521.6 \pm 5.4 \mathrm{~b}$ & $445.0 \pm 3.7 \mathrm{c}$ & $38.9 \pm 1.7 \mathrm{e}$ & $69.6 \pm 2.1 \mathrm{c}$ & $400.0 \pm 3.4 \mathrm{~d}$ \\
\hline \multirow[t]{2}{*}{3.0} & no & $\mathrm{i}$ & $\mathrm{i}$ & $\mathrm{i}$ & $\mathrm{i}$ & $\mathrm{i}$ & $\mathrm{i}$ \\
\hline & yes & $505.7 \pm 5.3 \mathrm{c}$ & $543.9 \pm 5.2 \mathrm{c}$ & $468.6 \pm 5.0 \mathrm{e}$ & $34.2 \pm 2.7 \mathrm{~d}$ & $68.4 \pm 3.0 \mathrm{c}$ & $455.1 \pm 4.8 \mathrm{e}$ \\
\hline
\end{tabular}

Vertical means with different letters differ significantly $(\mathrm{P} \leq 0.01)$ : i The system is unfeasible without supplementation.

\section{RESUMEN}

Modelación de estrategias de suplementación en la recría y engorda de novillos en el Sur de Chile. Un modelo matemático fue desarrollado para analizar sistemas de producción de carne bovina en el Sur de Chile. El estudio consideró la identificación de los componentes en diferentes estrategias usadas en novillos de carne, usando praderas con y sin suplementación y la recría seguida por una engorda a corral en invierno con ensilaje de praderas y granos. La validación de los resultados a pradera del modelo usando novillos Hereford de 200 kg PV contra resultados experimentales no mostró diferencias significativas $(\mathrm{P} \geq 0.01)$ entre los pesos finales simulados y los observados. En el estudio, fueron simuladas tres carga animal (CA) de 2, 2.5 y 3 novillos ha $^{-1}$ con y sin suplementación de ensilaje de pradera a una tasa de $5 \mathrm{~kg}^{\mathrm{MS}}$ novillo- día $^{-1}$ durante todo el período de alimentación. Las medias fueron comparadas por Diferencias Significativas Mínimas (LSD, $\mathrm{P} \leq 0.05$ ). Diferencias significativas se encontraron en los pesos finales, que disminuyeron en razón del aumento de la CA independiente del nivel de suplementación, aunque ésta tendió a reducir las diferencias entre las CA. Se simuló además la respuesta de los novillos en el período final de engorda a corral y con una ración base de ensilaje y granos. Los pesos finales difirieron entre CA y los resultados mostraron que la $\mathrm{CA}$ de 2.5 novillos ha-1, entregó el mayor ingreso al menor costo medio. Se concluye que una carga animal de 2.5 novillos ha ${ }^{-1}$ es factible si existe disponibilidad de suplementación, independiente del sistema a corral para la terminación.

Palabras clave: bovinos de carne, suplementación, pastoreo, modelos de simulación.

\section{LITERATURE CITED}

AFRC. 1993. Necesidades energéticas y proteicas de los rumiantes. 175 p. Agricultural and Food Research Council, Zaragoza, España.

Aguilar, C. 1997. Simulación de sistemas. Aplicaciones en producción animal. Colección en Agricultura. 241 p. Pontificia Universidad Católica de Chile, Santiago, Chile.

Aguilar, C.D., R.I. Allende, y J.S. Morales. 2003. Gestión de sistemas pecuarios. Colección en Agricultura. 633 p. Pontificia Universidad Católica de Chile, Santiago, Chile.

Aguilar, C., R. Vera, R. Allende, and P. Toro. 2006. Supplementation, stocking rates, and economic performance of lamb production systems in the Mediterranean-type region of Chile. Small Ruminant Res. 66:108-115.

Catrileo, A., y L. Goic. 2005. Introducción y perspectivas del rubro. In Catrileo, S.A. (ed.) Producción y manejo de carne bovina en Chile. Colección Libros INIA N ${ }^{\mathrm{o}}$ 16. p. 13-27. Ministerio de Agricultura, Instituto de Investigaciones Agropecuarias, Centro Regional de Investigaciones Carillanca, Temuco, Chile.

Catrileo, S.A., y G.G. Klee. 2005. La ganadería de carne en la pequeña agricultura. In Catrileo, S.A. (ed.) Producción y manejo de carne bovina en Chile. Colección Libros INIA No 16. p. 485-496. Ministerio de Agricultura, Instituto de Investigaciones Agropecuarias, Centro Regional de Investigaciones Carillanca, Temuco, Chile.

CSIRO. 1990. Ruminants. Feeding standards for Australian livestock. 266 p. The Australian's Commonwealth Scientific and Industrial Research Organisation, Victoria, Australia. 
Halvorson, M. 2003. Microsoft Visual Basic NET. Version 2003. 135 p. Mc Graw Hill/Interamericana de España, Madrid, España.

Hoover, S.V., and R.F. Perry. 1989. Simulation. A problemsolving approach. 400 p. Addison-Wesley Publishing Company, Reading, Massachussets, USA.

ODEPA. 2001. Compendio estadístico, silvoagropecuario 1990-2000. 169 p. Ministerio de Agricultura, Oficina de Estudios y Políticas Agrarias, Santiago, Chile.

Rojas, C., A. Catrileo, y J.L. Rouanet. 2004. Sistema de recría y engorda con novillos Hereford y cruzas con doble propósito, integrados a una sucesión de cultivos en el valle de la IX Región. p. 147-148. XXIX Reunión Anual Sociedad Chilena de Producción Animal (SOCHIPA), Villarrica, Chile. 13-15 de octubre. SOCHIPA, Santiago, Chile.
Rojas, C., y O. Romero. 1994. Sistema de recría-engorda de novillos Hereford, utilizando festuca con trébol subterráneo, en el valle de la IX Región. Agric. Téc. (Chile) 54:130-135 .

Tattersall. 2006. Sociedad El Tattersall S.A. Ferias de ganado. 17-10-2006. Available at http://www. tattersall-remates.cl (Accessed December 2007). 